\title{
Regaining a place from which to speak and be heard: In search of a response to the "violence of voicelessness"
}

\author{
Brigitta Busch \\ Department of Linguistics, University of Vienna \\ E-mail: brigitta.busch@univie.ac.at
}

\begin{abstract}
This paper is concerned with linguistic vulnerability to man-made trauma, displacement, and exclusion, as well as with strategies of resilience that valorise socially-depreciated resources within the linguistic repertoire. It focuses on an interview carried out within a transdisciplinary project which - from a medical, a psycho-therapeutical and a linguistic perspective - addressed interrelations between multilingualism, trauma and resilience. A close reading of the biographical narrative raises three main points. First, how a life in permanent precarity and suspense is lived as "violence of voicelessness" (Anthonissen) - as the loss of any acknowledged position from which one can relate oneself to the world by social action and interaction. Second, how the pressure of exclusion contributes to re-invoking earlier traumatic or stressful experiences. Finally, how (sometimes unexpected) linguistic resources can strengthen resilience. Such resources include an awareness of the potential that lies in what I would call a "heteroglossia of survival", in the possibility of mobilizing means of expression associated with the semiotic dimension of language (Kristeva), and in the struggle for recognition through which it becomes possible to re- position oneself, to regain a place from which to speak.
\end{abstract}

Keywords: trauma, resilience, voice, displacement, precarity, heteroglossia, linguistic repertoire, lived experience of language

\section{Introduction}

Whereas societies are still conceived of in categories of relative demographic stability and sedentarism, the number of displaced persons is increasing constantly on a worldwide scale. Undocumented migrants, persons without residence or work permits, asylum seekers, inhabitants of refugee camps, refugees who have been denied asylum, 'erased' people who have lost their citizenship as well as their legal existence subsequent to the drawing-up of new state borders - all these groups of people find themselves in a state of precarity which denies them fundamental rights.

In Giorgio Agamben's (1998) understanding, the political space of modernity tends, by imposing a sort of permanent state of emergency, to produce outcasts; i.e. groups of beings 
under the spell of law but not under its protection, thus reduced to 'bare life'. Drawing on Aristotle, Agamben distinguishes between the biological existence (zoe) and the political life of speech and action (bios). The notion of 'bare life' refers to a mode of being that is produced by the sovereign political realm through mechanisms of exclusion and measures of exception that, from ancient times on, have been essential to the constitution of the political body as such. 'Bare life' thus designates the homo sacer, the outcast reduced to nothing but existence. In today's times and societies, the exclusion from basic rights has become a mass phenomenon which affects various subgroups of displaced persons to differing degrees. In Agamben's view these outcasts represent an 'exception', but the mechanisms that made them into exceptions can be used at any time on anyone.

For Hannah Arendt, to whom Agamben refers amply, the stateless refugees and displaced persons during and after World War II are paradigmatic for the (totalitarian) denial of rights to those who are in most urgent need of them:

The paradox involved in the loss of human rights is that such loss coincides with the instant when a person becomes a human being in general without a profession, without a citizenship, without an opinion, without a deed by which to identify and specify himself - and different in general, representing nothing but his own absolutely unique individuality, which, deprived of expression within and action upon a common world, loses all significance.

Arendt (1952:302)

The aim of this paper is to shed light from a sociolinguistic perspective on what it means to be "deprived of expression within and action upon a common world", on how people live such a 'bare life' as a traumatic experience of silencing and voicelessness and how they cope with it in developing (sometimes unexpected) linguistic resources. I first discuss theoretical approaches to vulnerability and resilience as well as to voice and voicelessness which contribute to a better understanding of the language-biographical narrative that is subjected to a close reading in the following section. The interview was carried out within a transdisciplinary research project on traumatic experience, multilingualism and resilience. Finally, I argue that all three elements of the Bakhtinian triad of discourse, language and voice play an essential role in the process of coping with and recovering from traumatic experiences.

\section{Trauma and voicelessness}

In her work dealing with hearings of the Truth and Reconciliation Commission (TRC) in South Africa, Christine Anthonissen (2006a, 2006b, 2009) has approached, from the angles of sociolinguistics and critical discourse analysis, the topic of traumatic experiences and particularly of how distressing memories can be related in such a way that they are heard.

To define the notion of 'trauma', I will first invoke some points generally agreed upon in contemporary research on trauma (cf. van der Kolk, McFarlane and Weisaeth 2007). Traumatic experiences can have extremely severe and long-lasting consequences on the health of the affected persons. Such consequences include sudden exposure to overwhelming emotions ('flashbacks'), nightmares or panic attacks, a drive to re-enact traumatising situations, attitudes of avoidance, ('frozen state', 'psychic numbing'), partial loss of memory, different forms of 
somatization, and dissociation. The cause of a traumatic experience can be a single event, a series of repeated (sequential) events, or the continuous exposure to emotional stress.

In the context of forced displacement and migration, different causes can accumulate into a chain of stressful experiences: a situation of threat and persecution in the country of origin, distressing circumstances during the trajectory of migration (Fluchtweg), ongoing insecurity, experiences of exclusion, and deprivation of rights in the country of final destination.

In the attempt to understand the way in which trauma operates, scholars often refer to the ground-breaking work of the French psychiatrist Pierre Janet at the end of the $19^{\text {th }}$ and the beginning of the $20^{\text {th }}$ century. In his view, "emotional accidents" (his term for what we would today call "traumatic experiences") happen when one is exposed to a sudden change of the physical and, most importantly, social environment: a change so incisive that one is not able to adapt oneself because of a lack of time or vital resources. A disruptive event becomes an "emotional accident" when one is not able to assimilate such a lived event into one's personal perception, to relate it to previous experiences and memories (Janet 1904). The difficulty of putting traumatic experience into words, of representing it symbolically through language and integrating it into a narrative of the Self, derives precisely from this impossibility of assimilation and connection to the world of one's experiences. In this sense, the traumatic experience can also be conceived of as a sort of non-experience (Fischer 2012) that is lived as a fundamental disruption of the basic expectation that 'the world will go on'; the trust in what Edmund Husserl (1939/1985:51) has called das Undsoweiter, the 'and-so-on'.

The threatening power of a potentially traumatizing event thus always has to be considered in relation to a person's potential to cope with it (Fischer and Riedesser 1998). In many therapeutic approaches, priority is given to the construction (or imagination) of safe spaces and the development of resources that can strengthen resilience, rather than to a sometimes risky confrontation with the traumatic memory (Reddemann 2011). That different people experience potentially traumatizing situations and cope with them in different ways is a fact to which Lev S. Vygotskij (1994) already drew attention in a study carried out in the early 1930s on the emotional experiences (perezhivania) of three siblings from one family. From the children's differing reactions to the domestic violence they had suffered, he concludes that the social environment does not impact directly in a static way, but only through the way in which it is experienced and interpreted. This interpretation is dynamic, as it changes according to the development of each child. For Vygotskij (1994:19), the key to any human being's development lies in social interaction; in the development of what he calls "power of speech".

The focus of this paper is on how situations of exclusion or "exception" that are lived as traumatic experiences can lead to the loss or rather to the denial of the "power of speech", and how, eventually, this power can be redeveloped or re-appropriated. Drawing on an anthropological study in the context of the TRC hearings carried out by Alexandro C. Cuéllar (2005), Christine Anthonissen (2009) developed the concept of the 'violence of voicelessness' to characterize the effects of imposed policies of explicit and implicit censorship that are experienced by victims of violence as a silencing - or an expropriation - of their personal life stories. She deplores the fact that traumatized people are often not in a position "to contribute to a discourse in which they should be central participants" (Anthonissen 2009:99). As the concept of the 'violence of voicelessness' is central to my contribution, I will first briefly 
discuss the term "voice", referring to Mikhail Bakhtin, Maurice Merleau-Ponty and Dell Hymes.

In Bakhtin's (1981) conceptualization of heteroglossia, the notion of 'voice', along with those of 'discourse' and 'language', is one of the core elements (Todorov 1984): the term "discourse" (or "speech types") refers to (contradicting) worldviews that correspond to specific socialideological worlds, each of which is situated in time and space. Such ideological plurality over time condenses into linguistic differentiation, variation, or language change; in turn, the term "voice" points to the way in which individual speakers - through their linguistic choices drawing on and responding to others' voices - position themselves in relation to discourses and languages:

Consciousness finds itself inevitably facing the necessity of having to choose a language. With each literary-verbal performance, consciousness must actively orient itself amidst heteroglossia, it must move in and occupy a position for itself within it, it chooses, in other words, a "language".

Bakhtin (1981:295)

To understand what happens when the possibility to choose and to occupy a specific position within the social world is denied, I suggest that we turn to the French philosopher MerleauPonty (2002). In his phenomenological approach, Merleau-Ponty offers highly interesting reflections on language, which for him is first and foremost about positioning oneself in relation to the world and projecting oneself towards the other. Thus, language is not conceived of primarily as a system of symbolic representation, but as an intersubjective bodily gesture to open and to relate oneself to the other, to the world. In contrast, to have no place from which to speak results in a gesture of closure, in a freezing of the bodily movement, in a loss of voice, in a shutting-off from the world:

[...] the move towards the future, towards the living present or towards the past, the power of learning, of maturing, of entering into communication with others, have become, as it were, arrested in a bodily symptom, existence is tied up and the body has become "the place where life hides away".

Merleau-Ponty (2002:190-191)

Interestingly, Hymes (1996) introduces the concept of 'voice' from its opposite: from the denial of voice, which he demonstrates using the example of underprivileged groups in the United States. He then develops, in a Marxian sense, the notion of 'negative' and 'positive' freedom, whereby negative freedom is understood as "the freedom from denial of opportunity due to something linguistic, whether in speaking or reading and writing", while positive freedom is defined as "the freedom for satisfaction in the use of language". According to Hymes, these two kinds of freedom converge in the concept of 'voice', which encompasses "freedom to have one's voice heard, freedom to develop a voice worth hearing" (Hymes 1996:64).

From different angles, but in a complementary way, these concepts shed light on what it means to have or to not have voice, a social place to speak from. Trauma can entail a loss of voice, but equally a constant denial of voice can be lived as a traumatic experience. In a similar way, developing resilience and developing voice go hand in hand, voice being a result of resilience as well as one of its prerequisites. 


\section{Lived experience of language}

The empirical example that this paper is based on originates from a transdisciplinary pilot study ${ }^{1}$ which was carried out in the psychiatry ward of a hospital in Austria and explored the interrelationship between multilingualism, trauma and resilience. At the heart of the project was the concept of Spracherleben ('lived experience of language'). This concept, which foregrounds the intersubjective, bodily-emotional dimension of language, refers to how we perceive ourselves as speakers and how we believe ourselves to be perceived by others in particular situations of interaction (Busch 2015).

In the project we used a multimodal dialogical approach, in which a language-biographical narrative is elicited through the drawing of a language portrait (Busch 2012). Inviting the participants to speak about their linguistic repertoire, their lived experience of language, their language practices and linguistic desires, proved to be a suitable means to allow them to speak about their life trajectories without focusing on traumatic or otherwise stressful experiences. The fact that language can be conceived of in a twofold manner - as an emotional space of experience intimately tied to oneself and at the same time as an 'externalized object' - allowed the participants to regulate the level of proximity to or distance from their own lived experience (of language) at every moment of the interview. Whereas approaches to multilingualism in psychotherapy usually assume a dichotomy between an emotionally-loaded first language and a rather 'neutral' second language, we conceived of the linguistic repertoire in our approach as a complex ensemble of dispositions that reflect intersubjective (bodily and emotional) language experiences superimposed on one another along the life axis. Based on our earlier work (e.g. Busch 2012), we could expect that this would ease the access to remote layers of previous experiences.

In what follows, I offer a close reading of one of the language-biographical narratives generated in the course of the abovementioned project to explore how living a life in precarity, a life without a secure legal status, makes it difficult to develop one's voice and to be heard. I raise three main points: first, how a life in permanent precarity, suspense and anguish is lived as the "violence of voicelessness" - as the loss of any acknowledged position from which one can relate oneself to the world by social action and interaction; second, how exclusion, social isolation and the feeling of being locked in contribute to reinvoke earlier traumatic or stressful experiences; and third, how, in a countermove, (sometimes unexpected) linguistic resources can be developed to strengthen resilience.

\section{Isolation, anguish and anger - A life in suspense}

Mrs. L., who grew up in Romania, is at the time of the interview in her early forties. She speaks about the difficulties she had after her marriage in joining her husband, who lived as a migrant worker in Austria. Over a five-year period, during which she continued to live alone with her daughter in Romania, she struggled in vain to obtain a visa. She then decided to join her husband in Austria so that the family could be reunited. While father and son had a legal status, for some obscure reasons Mrs. L. and her daughter were denied residence permits. After 13 years of a

\footnotetext{
1 "Multilingualism and resilience - A transdisciplinary explorative pilot study" carried out in 2012-2014 by Martin Aigner (Psychiatry and Psychotherapeutic Medicine, Medical University of Vienna), Brigitta Busch (Department of Linguistics, University of Vienna) and Luise Reddemann (Psychotraumatology and Psychological Medicine, University of Klagenfurt); http://heteroglossia.net/Resilienz-und-Mehrsprachigkeit.121.0.html
} 
life in hiding, she finally obtained her permit. She relates her breakdown, which occurred shortly after the legalization of her status, to the endless Kampf mit Papiere [fight with documents] to which other problems accrue (illnesses, relocations, domestic disputes, water damage...). Living in precarity, in a permanent "state of exception" (Agamben 1998), means being at the mercy of unpredictable and incomprehensible decisions that concern vital interests and fundamental rights. Mrs. L. repeatedly insists on this aspect, as in the following quote:

ich kann mir [die Verweigerung der Aufenthaltsbewilligung] bis heute nicht erklären. Ich weiß nicht die Grund und ich weiß nicht diee $(2 s) /$ und jetzt bin ich endlich zu müde. [...] manchmal bin ich sauer, manchmal bin ich wütend, weil • denk ich mir, wenn ich hätte • längere Jahre gearbeiet, ((ea)) hätte v/・・viel erreicht auch für Familie und für mich [...].

'I cannot explain myself until today [the refusal of the residence permit]. I don't know the reason and I don't know this (2s)/ and now finally I am too tired. [...] sometimes I am sour, sometimes I am furious, because $\bullet$ I think if I had $\bullet$ worked for more years ((ea)) I could have achieved $\mathrm{m} / \bullet \bullet$ much for my family and for me $[\ldots]$.'

Mrs. L. describes her energy-consuming 13-year-long fight for recognition as a period in which she loses confidence in her internal and external environments as being structured, predictable and explicable - a feeling that, following Aaron Antonovsky's (1979) research on salutogenesis, is indispensable when it comes to coping with stressful experiences. In contrast, Mrs. L. sketches the possibility of a life in which things are "normal", structured and predictable:

ich hätte schon gern, a, a, normales Job, a fixes Job,/ dass ich auch wie alle andere normale Menschen, in - Arbeit gehe und komme,

'I would much like a, a normal job, a permanent job,/ that I go like all other normal people to $・$ work and come,'

In contrast, Mrs. L. gives an example of how she experiences precarity and insecurity in daily life:

L: Ahm (1,5s) das war so: Ich habe immer Angst gehabt, dass ich ah auf-geschoben werde,

I: Abgeschoben.

L: abgeschoben, //

I: Ja. //

L: und ich hab immer geguckt, wenn a Polizeiauto oder $<$ so $\bullet \bullet(($ leicht zittrig)) $>$ vorbei, ich war im Fenster, immer, das war • über zehn Jahre.

L: Ahm (1,5s) it was like that: I was always afraid, that I will be post-pelled,

I: Expelled.

L: expelled, //

I: Yes. //

L: and I always looked, if a police car or < so $\bullet(($ somewhat shaky $))>$ comes along, I was at window, always, that was over $\bullet$ ten years. 
Afraid of being discovered or denunciated, Mrs. L. tends, as she tells, to reduce her contacts outside the nuclear family insofar as possible.

L: Früher war ma gemobbt und von Nachbar und das war schwer, weil ich war ganze $\mathrm{Za}$ / Zeit zuhause mit Kinder. ((ea)) Meine Mann war in Arbeit [...] er [der Nachbar] hat so geschrien und so hat ah • - geschrien: „, Scheiß Ausländer!“ Und „, Gehts ihr weg! “ und, und hat so viel Schlüssel hier gehabt, hat alles zugesperrt, zehn Mal kon/ zu kontrolliert, ((ea)) und dann ich mu/ ich musste auch ab und zu in Garten mit Kinder. Weill das geht nicht, ne? //

I: Natürlich. Nein. //

L: nur drinnen und, und, und die Gardinen zu und Fenster zu

L: Before at home we were mobbed and by the neighbour and that was difficult, because I was at home all the to/time with the children. ((ea)). My husband was on work [...] he [the neighbour] shouted, and so ah he • - shouted: "Damned foreigners!" And "You go away!" and, and he had so many keys here, locked everything, con/controlled ten times, ((ea)) and then I ha/had to go every now and then with the children. Because it does not work, no? //

I: Of course. No. //

L: to be only inside and, and curtains closed, windows closed

In this sequence Mrs. L. speaks about an aspect of her life in precarity, which is so to say metaphorically represented by the neighbour: with his xenophobic utterances he denies her the right to be in Austria and gives her the feeling of being controlled and locked in. What she describes is a situation of confinement and of social isolation; a situation that requires that one become almost invisible and inaudible; a situation in which one has no position and can take no stance from which to speak and be heard. It corresponds to what Arendt (1952:302) says about the stateless refugee who "deprived of expression within and action upon a common world, loses all significance".

\section{Invoking past experience}

At another moment in the interview, Mrs. L. speaks about her childhood and youth in a Ukrainian-speaking village in Romania, highlighting specific memories linked to the minority background of her family. What she shares about her experiences and feelings connected to her life as a migrant without status and rights in Austria has its parallel in how she recalls the precarity of belonging to the marginalised Ukrainian-speaking minority in the totalitarian Ceaușescu state. Being locked in, policed, controlled, the experience of not having a language (or the 'right' language), not having a voice, is not new for her in the "state of exception" (Agamben 1998) in which she finds herself during her 13 years in Austria. Rather, this reinvokes earlier experiences.

In the late 1970s, at the time when Mrs. L. began school in her Ukrainian-speaking village, the Romanian language policy was oriented towards homogenization and Romanization. Schools with Ukrainian as medium of instruction were closed, the Greek Catholic Church to which Ukrainians in Romania mostly belonged was prohibited and transformed into a subunit of the Romanian Orthodox church. This policy led to massive assimilation, which found its expression 
in dramatically-dropping numbers of Ukrainians in the official statistics (Yuriychuk 2014:6061).

Mrs. L. remembers her first months in a school in which the teacher spoke only Romanian. For her, it is the moment when she first discovers that beyond the small community in which she lives there is a (linguistic) world to which she had to struggle to gain access:

mit sieben Jahren ich könnte keinee $\cdots$ - Wort Rumänisch. Und da war ich $・$ sauer, wütend, (1s)/ ich könnte gar nix mit Lehrerin kommunizieren erste halbe Jahr. [...] ich hab auch rumänische äh $\bullet$ Staatsbürgerschaft._Ich hab mich dann danach auch wie a Rumäner gefüllt, aber trotzdem, das, das in Kindheit war $\bullet / /$ für mich war verwirrend, komisch./ Auch schwierig hab ich empfunden./ Nicht jetzt nur auf Sprache, sondern ((ea)) vielleicht mehr auf meine Eltern, ich < weiß es nicht. ((leicht lachend)) > Weill (1s) mit sieben Jahre dann keine Wort, und in/ direkt in eine rumänische Schule, das war schon/

'with seven years I did nooo $\cdots$ - word Romanian. And I was - sour, angry, (1s)/ I could not at all communicate with the teacher the first half year. [...] I have the Romanian eh - - citizenship._I after that also felt like a Romanian, but nevertheless, that, that in childhood was $• \bullet /$ for me confusing, strange./ Also as difficult I experienced it./ Not only because of language, but ((ea)) maybe more because of my parents, I < don't know. ((laughing a bit))> Because (1s) with seven years then no word, and in/ directly in a Romanian school, that was quite/'

"Sour" and "angry" are the very words Mrs. L. used when in the interview she spoke about her later life in Austria and about not understanding why she and her daughter were not granted residence permits. In this quote, these same words refer again to a case of non-understanding: a non-understanding of the language the teacher speaks and of the situation in which the teacher speaks another language than the learners. She discovers how the limits of her own linguistic repertoire constitute an obstacle to accessing a wider world. In her narrative, the feeling of being linguistically locked-in is linked to a feeling of disappointment and anger.

Speaking about her childhood and youth in the village, Mrs. L. also addresses the problem of being exposed to a permanent pressure to conform:

$<$ sso war die Mentalität oder ich weiß es nicht. ((schnell)) >((ea)) Aber das war alles - geh/ „Wir gehen in die Kirche, weil die Nachbarn gehen auch." Das hat mich so genervt! [...] ,,Was sagt die Nachbar?". „Was sagt die Onkel?“. Oder ((ea)) sa/ hat meine Mutter gesagt: „Darf ma ned schlafen bis neun, weil Leute sehen keine Rauch. “/ So und dann müss ma einheizen in die Früh und dann kann ma noch a bissi legen

$<$ sso was the mentality or I don't know. $(($ fast $))>(($ ea $))$ But that was all $\bullet$ go/ "We go to church because the neighbours do the same." This annoyed me so! [...]"What does the neighbour say?". "What says the uncle?". Or ((ea)) sa/ said my mother: "One must not sleep until nine, because the other people don't see smoke."/ So and we had to light a fire in the morning and then could lie a little longer 
Mrs. L. concludes the sequence on her childhood and youth in Romania by saying: wir waren sehr zugespert mit Kommunismus./ Mit Ceaușescu ('we were very locked up with communism./ With Ceaușescu'). Mrs. L. recalls how she was irritated by the pressure exerted by her mother to not stand out; to do what everybody did or at least to pretend to do so. The pressure to conform that exists in a group that constitutes itself or is constituted by others as a community can be particularly strong in situations where a minority is singled out and discriminated against. It can then be experienced as a double pressure: on the one hand to conform to the language and the assimilatory discourse of the majority, and on the other to conform to the reaction of the minority group to retrench or shrink into itself. Jacques Derrida (2014a, 2014b) discusses a similar phenomenon, drawing on his own experience as a Jewish boy in Algeria expelled from school as a result of the anti-Semitic regulations of the French colonial regime during the Vichy era. For Derrida, this biographic event has, as he elaborates, the meaning of a traumatic key experience of non-belonging and at the same time of a first revolt. The child's revolt is directed against the racist, anti-Semitic 'gregarism' of the followers of the regime as well as, strangely, against the sometimes similarly gregarian reactive solidarity (solidarité réactive) of a community that in a move of self-protection withdraws into itself.

Mrs. L. refuses and criticizes her mother's attitude regarding the neighbours, the uncle, the rumours in the village, as a mimicry: one does not necessarily have to conform entirely but one has to at least pretend to do so. This is a form of the 'doublethink' which Tzvetan Todorov (1985), drawing on his own experiences in post-war Bulgaria, identified as a characteristic phenomenon in totalitarian countries. Elaborating on Bakhtin, he notices an incoherent copresence of two discourses responding to a schizophrenic situation - a public one that conforms to a stable ideology (vérité de conformité), and a private one that adapts itself to the contingent circumstances of the moment (vérité d'adéquation). Following Todorov, the transition from one discourse to the other, the choice of the adequate verbal registers, is perfectly mastered by every speaker without ever having to be learnt. In Todorov's view, such a duality is not restricted to totalitarian circumstances, but in no other circumstance is the subject threatened in such a fundamental manner by the possible confusion between the public and the private discourses that need to be meticulously separated at every moment.

\section{Linguistic resources for resilience}

A third aspect that came up in the interview is how, in a countermove to the traumatic experience of living in a 'state of exception', of permanent insecurity and social isolation, unexpected and underestimated linguistic resources can be developed and can become a means of strengthening resilience. Such resources include an awareness of the potential that lies in what I would call a "heteroglossia of survival"; in the capacity to mobilize means of expression associated with the semiotic dimension of language (Kristeva 2002), as well as in the struggle for recognition through which it becomes possible to re-position oneself, to regain a place from which to speak.

Mrs. L. tells us that she could occasionally escape from isolation and communicate with neighbours who had migrated from Bosnia, Bulgaria and Turkey. Their different languages as well as Mrs. L.'s Ukrainian helped to develop a common way of speaking: 
Und da hab ich a bissi auf $<$ Ukrainisch ((lachend)) $>$ und, und, und $\cdot$ war bissi gemischt, und $\bullet$ is gegangen. Wir könnten uns $\bullet$ / wie sagt ma, verständigen.

'And then I did a little in $<$ Ukrainian ((smiling)) $>$ and, and, and $\bullet$ was a little mixed, and $/ \bullet$ it worked. We could $\bullet$ h/ how does one say, communicate.'

In her words, Mrs. L. describes a kind of translanguaging that draws on the heterogeneity of the linguistic resources and repertoires that she and her neighbours bring into their interactions. The common ground is not a specific lingua franca (e.g. German), but a heteroglossic speech. Translanguaging here appears not to be primarily a means of stylization or of identification with a group, but an attempt to break through the imposed speechlessness, thereby making social and linguistic survival possible. Whereas questions of language and migration are mostly dealt with in terms of an assumed dichotomy between the language of the country of origin and the language of the country of destination - whereby the degree of competence in the language of the 'host country' is often considered to be a yardstick by means of which to measure successful or failed 'integration' - Mrs. L.'s example makes it obvious that the entire linguistic repertoire plays a pivotal role when it comes to gaining a foothold in a new environment.

Like most of the persons who were interviewed within our project on language and trauma, Mrs. L. mentions specific forms of speech that could be summarized as forms that foreground the poetic or semiotic dimension of language:

Und auch, auch, auch das Singende in die Kirche, das / das gefällt mir • so, so von •• Hören. • Von • / weil die Wörter is/ die Bedeutung ist gleich.

'And also, also, also the chant in the church, that / I like that $\bullet$ so, so from $\bullet \bullet$ hearing. $\bullet$ From• / because the words is/ the meaning is the same.'

In the rhythmic intonations of the liturgical chants, the priority is not on the transfer of information but rather on the material qualities of the sign, such as rhythm and intonation. This is what Julia Kristeva (2002) calls "semiotic speech", which in her opinion is characterized by heterogeneousness towards signification. Drawing on the babbling and rhythmic intoning in early childhood, the semiotic is reinvoked in poetic and 'musical' language or in language games. Kristeva ascribes a particular relevance to this semiotic dimension of language in situations of crisis, when "the speaking subject [is] threatened by the collapse of the signifying function" (Kristeva 2002:101). A momentary loss of the signifying function can also manifest itself in the case of traumatic experience. The difficulty of putting traumatic experience into words, of representing it symbolically through language and integrating it into a narrative of the Self, contributes to the foregrounding of this other semiotic dimension of language.

Finally, in the interview Mrs. L. expresses her strong desire to improve her German, which she learnt, as she relates, by watching TV and reading magazines or books. At several points in the interview Mrs. L. insists on how important German is for her: 
Ja. Das liegt mir am Herzen. [...] ohne deutsche Sprache ich könnte mir nicht vorstellen, hier zu leben, mein ich, • dass es ohne eine Sprache in eine Land, is sehr schwer. [...] Ahm $・$ ich bin froh, dass ich die Sprache $・$ gelernt habe, $\bullet((e a))$ ahm $\bullet$ ich bin noch nicht zufrieden, ・ * ich möchte gern $(2,5$ s) / ich mach das fast wie perfekt [...] ich finde sehr wichtig, weil ich hier lebe und $\cdots$ mit meine Kinder und Familie/ und gefällts mir auch. Kann man auch in mehrere $\bullet$ Länder • benützen $\bullet \bullet$ is für mich is a Fremdsprache, $(1,5 s)$ ahm (1,5s) ja.

'Yes. It is dear to my heart. [...] without the German language I could not imagine living here, I think • that without a language in a country it is very difficult. [...] Ahm $\bullet$ I am glad that I learnt $\bullet \bullet$ the language, $\bullet(($ ea) $)$ ahm $\bullet$ I am not yet satisfied, $\bullet ・$ I would like $(2,5 \mathrm{~s}) /$ that I do that almost perfectly [...] I find very important because I live here • • with my children and my family [...] $\bullet$ and I like it too. One can use it in $\bullet$ several countries $\bullet$ is for me is a foreign language, $(1,5 \mathrm{~s})$ ahm $(1,5 \mathrm{~s})$ yes.'

In several of the interviews carried out in the course of our research project, interviewees expressed their ambivalent attitudes towards German. They perceived it as a language that is indispensable and highly desirable but at the same time almost unattainable. This shows the impact of the paternalistic 'integration through language' discourse that stipulates that one does not just have to learn German but that one has to want to learn it, because it is for one's own good (Dorostkar 2012). Mrs. L.'s insistence on linguistic perfection and, as she explains later in the interview, on mastering the grammar suggest that this discourse does not foreground the role of language in everyday communication, but linguistic normativity as a gate-keeping device. On the level of the lived experience of language, this means that speakers perceive themselves - through the eyes of an imagined other - as deficient, knowing that they will never be acknowledged as legitimate speakers. On the other hand, the wish to speak German also corresponds to Mrs. L.'s desire to regain ground, a stance from which she can again relate to the world. This idea is expressed in the above quote in which Mrs. L. evokes the possibility that German can also grant access to other countries.

When Mrs. L., after 18 years of waiting and stressful precarity, finally obtained a residence permit in Austria, she first reacted by allowing herself to live out the accumulated exhaustion. Only towards the end of her stay in the clinic, at the time when the interview was carried out, did she become aware that her new status offered greater predictability and security and could allow her to overcome the compulsion to make herself invisible and inaudible. Regaining a place from which she can speak means that she can position herself in relation to others and, step by step, overcome the violence of voicelessness.

\section{Conclusions}

As one can understand from Mrs. L.'s narrative, the denial of fundamental rights - in her case, for example, the right to a family life - that goes hand in hand with conditions of displacement and precarity is experienced, with regard to language, on different levels: on the level of discourse, xenophobic and racist discourses (represented in Mrs. L.'s narrative by the hostile neighbour), as well as legal regulations and bureaucratic practices that express policies of exclusion, can be experienced as a threat to one's existence. On the level of language use, the experience of being constantly and exclusively judged on one's competence in a single monolanguage (the official language of the country of arrival) can be lived as a humiliation and 
offence against one's dignity. On the level of voice, the refusal of a legitimate position in the social world makes it extremely difficult to position oneself as a speaker with regard to others.

These multiple ways in which one's quality and integrity as a speaking subject are denied can be lived, as expressed by Mrs. L., as a long-lasting painful and traumatizing stress. At the same time, her narrative reveals a remarkable ability throughout her life trajectory to develop strengths and resources when confronted with extremely difficult situations: she manages, after 5 years of imposed separation, to reunite her family; she fights courageously for another 13 years to obtain residence permits for her daughter and herself; she discovers the power of the poetic, semiotic dimension of language that allows for relaxing moments; she develops specific heteroglossic practices to communicate with migrant women next door; in order to be able to relate herself to a wider world she teaches herself German and, after her long years of a life in suspense, she makes considerable efforts to engage in a professional life.

As Reddemann (2011) explains, recovery from trauma cannot be conceived of as restitutio ad integrum but only as a process that leaves scars. It cannot be seen simply as an individual process, but rather as equally dependent on the immediate social environment and the larger socio-political framing. One of the factors that can help to strengthen resilience is the acknowledgment of the suffering that one went through and the possibility of integrating one's own traumatic experience into a bigger narrative that allows, at least to some extent, to make this experience understandable for oneself and for others. But it is equally important to acknowledge and value personal resources that people can rely on or are able to develop; e.g. the linguistic resources that displaced people bring with them or develop according to their immediate needs. And finally it is crucial to be out of danger, to be in a situation that is perceived as safe and secure and to become part of social networks through which one can reopen and re-position oneself towards others and the world. Only then can one find ways to break through the "violence of voicelessness", to again develop "expression within and action upon a common world" (Arendt 1952:302), to gain the "freedom to have one's voice heard, freedom to develop a voice worth hearing" (Hymes 1996:64).

\section{References}

Agamben, G. 1998. Homo sacer: Sovereign power and bare life. Stanford: Stanford University Press.

Anthonissen, C. 2006a. The language of remembering and forgetting. Journal of Language and Politics 5(1): 1-13.

Anthonissen, C. 2006b. Critical discourse analysis as an analytic tool in considering selected, prominent features of the TRC testimonies. Journal of Language and Politics 5(1): 71-96.

Anthonissen, C. 2009. Considering the violence of voicelessness: Censorship and selfcensorship related to the South African TRC process. In R. Wodak, B. Auer, G. Borea (eds.) Confronting traumatic pasts. An international comparison. Wien: Passagen Verlag. pp. 97-122.

Antonovsky, A. 1979. Health, stress and coping. San Francisco: Jossey-Bass Publishers.

Arendt, H. 1952. The origins of totalitarianism. New York: Harcourt Brace. 
Bakhtin, M. 1981. Discourse in the novel (1934-35). In M. Bakhtin, The dialogic imagination (ed. Michael Holquist). Austin: University of Texas Press. pp. 259-422.

Busch, B. 2012. The linguistic repertoire revisited. Applied Linguistics 33(5): 503-523.

Busch, B. 2015. Expanding the notion of the linguistic repertoire: On the concept of Spracherleben - the lived experience of language. Applied Linguistics 36 (electronic version). Available online:

http://applij.oxfordjournals.org/content/early/2015/07/23/applin.amv030.abstract.

Cuéllar, A. C. 2005. Unravelling silence: Violence, memory and the limits of anthropology's craft. Dialectical Anthropology 29(2): 159-180.

Derrida, J. 2014a. Avouer - l'impossible. "Retours", repentir et réconciliation (1998). In J. Derrida, Le dernier des Juifs. Paris: Galilée. pp. 13-65.

Derrida, J. 2014b. Abraham, l'autre. In J. Derrida, Le dernier des Juifs. Paris: Galilée. pp. 67126.

Dorostkar, N. 2012. Linguistischer Paternalismus und Moralismus: Sprachbezogene Argumentationsstrategien im Diskurs über, Sprachigkeit'. Aptum 1: 61-84.

Fischer, G. and P. Riedesser. 1998. Lehrbuch der Psychotraumatologie. Berlin: Springer.

Fischer, M. 2012. "Die Welt ist fort, ich muss dich tragen" (Celan) - Zum sprachlichen Umgang mit Grenz-(Nicht-)Erfahrung. In E. Angehrn and J. Küchenhoff (eds.) Macht und Ohnmacht der Sprache. Philosophische und psychoanalytische Perspektiven. Weilerswist: Velbrück. pp. 137-160.

Husserl, E. 1939/1985. Erfahrung und Urteil. Untersuchungen zur Genealogie der Logik. 6. Aufl. Hamburg: Meiner.

Hymes, D. 1996. Ethnography, linguistics, narrative inequality: Toward an understanding of voice. London: Taylor \& Francis.

Janet, P. 1904. L'amnésie et la dissociation des souvenirs par l'émotion. Journal de Psychologie Normale et Pathologique 5: 417-53.

Kristeva, J. 2002. From one identity to an Other (1975). In K. Oliver (ed.) The portable Kristeva. Updated edition. New York: Columbia University Press. pp. 93-115.

Merleau-Ponty, M. 2002. Phenomenology of perception. London: Routledge \& Kegan Paul.

Reddemann, L. 2011. Psychodynamisch Imaginative Traumatherapie PITT - Das Manual. Stuttgart: Klett-Cotta.

Todorov, T. 1984. Mikhail Bakhtin: The dialogical principle. Manchester: Manchester University Press. 
Todorov, T. 1985. Bilinguisme, dialogisme et schizophrénie. In Collectif, Du bilinguisme. Actes du colloque. Paris: Denoël. pp. 11-38.

Van der Kolk, B., A. C. McFarlane and L. Weisaeth. 2007. Traumatic stress. The effects of overwelming experience on mind, body and society. New York, London: The Guilford Press.

Vygotskij, L. S. 1994. §14. The problem of the environment (1934). In R. van der Veer and J. Valsiner (eds.) The Vygotsky reader. Hoboken: Wiley-Blackwell. pp. 338-354.

Yuriychuk, Y. 2014. The Ukrainian minority in Romania: Problems of preserving national identity. In M. Brie, I. Horga and S. Şipoş (eds.) Ethnicity and intercultural dialogue at the European Union Eastern Border. Cambridge: Cambridge Scholars Publishing. pp. 54-64. 